\title{
SOCIAL VARIABLES AND ROAD SAFETY PRACTICES AMONG TAXI DRIVERS IN UYO METROPOLIS, AKWA IBOM STATE, NIGERIA
}

\author{
Asuquo I. Enyim \\ Department of Physical \& Health Education, Faculty of Education. University of Uyo, \\ Akwa Ibom State, Nigeria
}

\begin{abstract}
The study was conducted to investigate the influence of social variables on road-safety practices among taxi drivers in Uyo Metropolis of Akwa Ibom State. Specifically, the influences of age, educational qualifications, marital status, income level, family size and beliefs about causes of road traffic accident on road-safety practices of taxi drivers were examined. Six research questions and six hypotheses were generated to guide the study. A survey design was used for the study. A sample size of 147 (30\%) were selected using simple random sampling technique at the Drivers' Union meeting-hall through the co-operation of their leaders. The instrument for data collection was a researcher's constructed questionnaire titled "Social Variables and Road Safety Practices Questionnaire (SVRSPQ)', The instrument was pretested using Cronbach's alpha statistics and a reliability coefficient of .78 was obtained. Simple percentage was used to answer the research questions while Chi-square was used for test of hypotheses at .05 probability level of significance. Findings revealed that age, educational qualification, marital status, income level, family size and beliefs about causes of road traffic accident all had positive influences on the road-safety practices of taxi drivers in Uyo metropolis. Intensive road-safety/health education campaign was recommended to inculcate safety-consciousness among all drivers and other road users in Uyo Metropolis and other parts of the state.
\end{abstract}

Keywords: ROAD SAFETY, SOCIAL VARIABLES

DOI: $10.7176 / \mathrm{JCSD} / 46-08$

Publication date:March $31^{\text {st }} 2019$

\section{Introduction}

Commercial vehicles are the major means of transportation in most cities of Nigeria till these present days. According to Abraham, Ezeque, Umeh and Ekanem (2010), a large percentage of the population does not own personal vehicles and therefore depend on commercial means of transportation to move from one place to the other. The authors enumerated commercial vehicles (for human transportation) commonly available in most Nigerian cities and State capitals as Uyo metropolis to include taxies, buses and the tricycles that had been officially adopted to replace the motorcycles in most Nigerian state capitals and cities in recent times. Bun (2012) stated that the safety of these commercial vehicles on our roads and highways is a function of good and conscientious driving, good maintenance of vehicles, good roads and committed road-safety practices among the drivers and other road users. However, the taxi drivers are known to constitute a very high proportion of fatalities in most cities and highways leading to high rates of road traffic injury (Asafe, Ingale, Shumey \& Yang, 2015).

Road traffic accident (RTA) is a common issue of great concern in most parts of the world because the number of road traffic injuries increases yearly, especially in the developing countries. According to Tiruneh, Dachew and Bifftu (2014), road traffic injury has become one of the major public health challenges that require consorted efforts for effective and sustainable control. The term "road traffic accident" may be defined as unintentional collision of one motor vehicle with another, a stationary object, or a person, resulting in injuries, death and/or loss of properties. Accident on the other hand, can generally be described as sudden-unplanned happenings, sometimes resulting in injuries, loss of life or damage to properties at any point in time, in any place or environment, such as homes, industries, roads, etc (Gupta \& Ghai, 2007).

According to World Health Organization (WHO) (2004), road traffic accident is one of the major noncommunicable disease factors that claim great number of lives abruptly or sometimes result in permanent disabilities. Furthermore, WHO (2009) also noted that the developing countries bear the brunt of fatalities of road traffic crashes; and has indicated that about $90 \%$ of the global lost due to road traffic injuries from road traffic accidents occur in the developing countries. Bun (2012) asserted that an increasing number of road 
crashes lead to an alarming rate of morbidity, mortality and disability from road traffic injuries in Nigeria. The author cited lack of adequate preventive measures to curb the menace of road traffic accident as one of the major problems that affect the country; adding that road traffic accident has become the leading cause of death to adolescent and young adults in the country. Similarly, Asogwa (2007) acknowledged that road traffic injury is one of the major public health problems in Nigeria.

Lum and Reagan (1996) stated that the causes of road traffic accident can be broadly divided into three groups: the driver factors, vehicular factors and the roadway factors. According to these authors, the driver factors alone contribute about 57 percent of accident occurrence annually in most developing countries. The driver factors refer to all factors that are related to the drivers and his concern for other road users. These include the driver's behaviour and attitude, including his drugs and alcohol use, his visual acuity and auditory ability, decision making ability and reaction time. The vehicular factors can be divided into vehicle design and maintenance, including safety-factors of the vehicles such as seatbelts and airbags. A well designed and adequately maintained vehicle is less likely to get involved in accident if driven by a well trained and safety conscious driver (Asafe et al, 2015).

Bun (2012) explained that the roadway factors include road design and maintenance and these also contribute to numerous cases of road traffic accidents. Unfortunately, most Nigerian roads and highways are so bad and are described to be among the worst and most dangerous in the world. The author reiterated that road traffic injuries are characterized by physical, emotional and socio-economic implications in most nations of the world. The global economic lost from road traffic accident on yearly bases has been estimated at 518 billion United State dollars. Nigeria alone has been estimated to loss about 80 billion Naira annually, to road traffic accidents and their resulting traffic injuries (Agbonkhese,Yisa,Agbonkhese, Akanbi, Aka \& Mondigha, 2013).

Blanchad and Tabloshi (2006) stated that road traffic accident has caused greater threat to human health than some of the most dreadful infectious diseases and that is why the prevention of road traffic injuries has been included as part of public health programme across most nations of the world. According to these authors, road accident ranges from auto-crash of big vehicles, taxies, with other vehicles, resulting in moderate to severe traffic injuries, as fractures, head injuries, deep wounds and rupture of internal organs and/or loss of lives in many circumstances. Sumaila (2013) acknowledged that road traffic accidents have claimed more lives than deaths resulting from all communicable diseases put together, including the dreadful Acquired Immune Deficiency Syndrome (AIDS). Broughton (2005) suggested that accident prevention can be achieved through positive approach to safety education and strict adherence to sustainable road safety practices by drivers and other road users for protection of lives and properties.

Road-safety practices encompass actions and procedures that are intended to prevent accident on our roadways. Asogwa (2007) opined that the promotion of ideal road-safety provides opportunity to all drivers and other road users to prevent high incidence of accident for the overall benefits of all and the entire society. This is one of the reasons why the Road Safety officials often get out to the roads to sensitize commercial drivers and other motorists on safety consciousness, which are valuable in the prevention of accidents and protections of lives and properties (Abraham et al, 2010).

The road-safety practices are valuable and mandatory for prevention of casualties from our roads. The term "road-safety" is a broad concept that has series of meanings to different people at different applications. Road-Safety Practices" refers to activities and precautions that are taken to improve road-use and safety, which aimed at reducing human related risks and casualties on the road. Gavin (2000) highlighted common road-safety practices to include: mandatory training of people to have adequate skills, implementation of safety laws and standards to ensure due compliance in the recommended safe-ways; driver's periodic medical check-up to ensure fitness, physically, socially and mentally; including registration and issuing of licences to all motorists after the driver's training. The road-safety practices are necessary for the overall good of all road users. They are ideal practices to be imbibed by all road users whether young or old, motorists or cyclists, including the pedestrians (Abraham et al, 2010).

Alex and Cavel (2008) defined social variable as social custom such as social class, age or the housing type occupied by individuals. The authors explained that social variables are the social characteristics that influenced the people's safety practices in their various works; such as age, educational qualification, income level, marital status and family size. According to Trochim (2006), a variable is any entity that can take on different values in any given situation or study. For example, 'age' can be considered as a variable because it can take different values for different people or same person at different times. Similarly, Lawrenzo (2006) pointed 
out that social variables are logical set of attributes; with people being the carriers of those attributes. According to this author gender can be regarded as a variable with two attributes of male and female.

Asefa et al (2014) acknowledged that the drivers variable contribute to their involvement in traffic accident. The authors asserted that the commercial drivers' lower educational status tend to influence more incidence of road traffic accident than private drivers with higher educational status. The authors further explained that education helps to pave ways; enabling people to have adequate information and provides proper understanding of the necessity of involvement and practice of road-safety principles. In a similar way,

Diez-Roux (2005) viewed social variables as human attributes and factors that influence human behaviour which can be measured in scientific research or epidemiological studies. The author affirmed that social variables include age, gender, beliefs, educational level, income level, region of residence etc. The driver's variables that contribute to road traffic accident are those factors that relate to their attitudes, beliefs and behaviours in their daily driving operations on the roads (Agbonkhese et al, 2013). The component of the driver's related road-safety practices for prevention of road traffic accident include: Mandatory drivers training before obtaining licenses; adequate maintenance of vehicles; avoidance of risky behaviours while driving; avoidance of illicit consumption of alcohol and other intoxicants; regular medical check up and ensuring adequate nutrition and rest.

\section{Statement of the Problem}

Road traffic accident (RTA) is a serious threat to human health and existence in most Nigerian state capitals and cities, including Uyo metropolis. It is one of the major public health issues that affect most nations of the world, specially the developing countries. The high rate and frequent occurrence of road traffic crashes on our roads has become one of the leading causes of death in the country over the years (Bun, 2012). The frequent involvement of taxi drivers and other motorists in such traffic crashes in most state capitals and cities across all states of the federation has contributed to the high death- toll in the country. Akambi, Aka, and Mondigha (2013) highlighted that road traffic crashes always result in various degrees of injuries, loss of lives and properties characterized by great emotional and financial constraints on the families of the victims, the loved ones, friends and colleagues due to prolonged hospitalization, protracted stay at traditional borne healers' homes or the actual death of victim in many circumstances.

Abraham et al (2010) observed that taxi drivers and other commuter's motorists in most Nigerian cities and state capitals are often very careless to ignore basic road safety practices, including violation of traffic rules and orders because they are always hurrying to carry more passengers to get adequate financial returns. The result of such carelessness and impatience among the drivers always lead to several casualties associated with increased morbidity, mortality and disabilities among drivers, their passengers and other road users. It was against this backdrop, that the researcher as a serving health educator in one of the public hospitals in the state decided to carry out this study to investigate the influence of social variables on road-safety practices among taxi drivers in Uyo-metropolis, with the aim of contributing to reduce the number of road traffic accidents in the metropolis and other parts of the state through public health education to enlighten and inculcate safety consciousness among the taxi drivers.

The purpose of the study was to examine the social variables that influence the road-safety practices among taxi drivers in Uyo Metropolis of Akwa Ibom State. Specifically, the study set out to achieve the following six objectives:

1. Determine the influence of age on road-safety practice among taxi drivers in Uyo Metropolis, Akwa Ibom State.

2. Examine the influence of educational qualification on road-safety practices among taxi drivers in Uyo metropolis, Akwa Ibom State.

3. Examine the influence of marital status on road-safety practices among taxi drivers in Uyo metropolis, Akwa Ibom.

4. Examine the influence of family size on the road-safety practices among taxi drivers in Uyo metropolis, Akwa Ibom State. 
5. Assess the influence of income level on road-safety practices among taxi drivers of Uyo metropolis, Akwa Ibom State.

6. Examine the influence of beliefs about causes of RTA on road-safety practices among taxi drivers in Uyo metropolis, Akwa Ibom State.

The following six research questions were generated to guide the study:

1. To what extent will age influence road-safety practices among taxi drivers in Uyo metropolis of Akwa Ibom State?

2. To what extent will educational qualification influence road-safety practices among taxi drivers in Uyo metropolis of Akwa Ibom state?

3. To what extent will marital status influence road-safety practices among taxi drivers in Uyo metropolis of Akwa Ibom state?

4. To what extent will family size influence road-safety practices among taxi drivers in Uyo metropolis of Akwa Ibom state?

5. To what extent will income level influence road-safety practices among taxi drivers in Uyo metropolis of Akwa Ibom state?

6. To what extent will beliefs about causes of RTA influence road-safety practices of taxi drivers in Uyo metropolis of Akwa Ibom stat

The following six hypotheses were formulated from the specific objectives to guide the study:

1. Age will not significantly influence road-safety practices among taxi drivers in Uyo metropolis, Akwa Ibom state.

2. Educational qualification will not significantly influence road-safety practices among taxi drivers in Uyo metropolis, Akwa Ibom state.

3. Marital status will not significantly influence road-safety practices among taxi drivers in Uyo metropolis, Akwa Ibom state.

4. Family size will not significantly influence road-safety practices among taxi drivers in Uyo metropolis, Akwa Ibom state.

5. Income level will not significantly influence road-safety practices among taxi drivers in Uyo metropolis, Akwa Ibom state.

6. Beliefs about causes of RTA will not significantly influence road-safety practices among taxi drivers in Uyo metropolis, Akwa Ibom state.

The study on social variables and road-safety practices among taxi drivers in Uyo metropolis, Akwa Ibom state was carried out using the following research methods: A descriptive survey design was used for the study. The design was considered most appropriate because it allowed the researcher to collect first hand (primary sources) information from large population of taxi drivers in their natural settings for the purpose of providing detail descriptions. The researcher obtained data through the use of questionnaire.

The study was carried out in Uyo metropolis, Akwa Ibom state capital in the south-south geopolitical zone of Nigeria. Uyo town became a state capital on September 23, 1987 following the creation of Akwa Ibom State from the erstwhile Cross River State (Akwa Ibom State Diary, 2014). The metropolis can be accessed via Ikot Ekpene Road, Abak Road, Itu Road as well as Aka Road, Oron Road and Nwaniba Road. Transportation in Uyo metropolis is mainly by taxi, buses and tricycles, popularly known as 'Keke.' The population of Uyo metropolis, according to the 2006 Nigerian Census was 554,906 (covering the urban extension of Uyo Township to nearby areas Itu and Uruan (The Nigerian Political Census, 2006). 
The population for this study comprised all taxi drivers in Uyo metropolis; especially those drivers who had driven in the metropolis for at least, 3 month before the study, particularly those who had fulfilled the necessary registrations with the state ministry of transport and membership of the Taxi Drivers' Unions. The total population of taxi drivers at the time of this study (June to November 2016) was 490 and were operating in 5 major access routes, namely, Abak Road-Ikot Oku Ubo Junction, Aka-Nung Udoe Road, Oron road, Nwaniba Road and Ikot Ekpene Road. The taxi drivers in Uyo metropolis were only permitted to use the main routes without going into the streets except on special arrangement and chartered drop (Uyo Metropolis Taxi Driver's Unions).

A sample size of $147(30 \%)$ was drawn for the study. Ndiyo (2005) recommended that a sample size should statistically be made up of 15 to $30 \%$ of the population. The author further explained that a smaller population can be studied entirely as sample. Therefore, the $30 \%$ of the population used as sample in this study is considered appropriate based on the size of the population, and the fact that the entire taxi drivers population cannot be easily reached due to the nature of their jobs. The respondents were selected using simple random sampling techniques at their union meetings. Each of the taxi's routes as mentioned above in the metropolis also served as a cluster for the study. The numbers of drivers from each of the clusters were as followed: Abak Road axis- 118 drivers; Aka Road - 69 drivers; Oron Road- 94 drivers: Nwaniba road- 100 and Ikot Ekpene Road -109 drivers, totalling 490 , of which $30 \%$ of the drivers from each of the five routes were selected for the

The researcher developed instrument titled "Social Variable and Road Safety Practices of Taxi-Drivers Questionnaire (SVRSPQ) were used as the only instrument to elicit information for the study. The questionnaire had two sections, namely section A and B. Section A provided information on personal demographic data of the respondents, while section $\mathrm{B}$ elicited information on road-safety practices of the taxi drivers.

The face and content validity of the instrument was done by submitting the questionnaire to three experts, two from the Department of Physical and Health Education and one from Measurement and Evaluation for necessary correction. This was done to make sure that the instrument measured what it intended to measure. A final copy of the instrument (SVRSPQ) was produced based on the corrections of the experts.

The reliability of the instrument was established by administering the questionnaire on a group of thirty taxi drivers that were not included in the study, but who were assumed to have equivalent social characteristics with the respondents in the study in Calabar Municipality, a sister state capital in the same South-South geopolitical zone. Cronbach alpha statistics was used to determine the reliability of the instruments. A reliability coefficient of .78 was obtained, which indicated that the instrument was reliable.

Descriptive statistics (percentage) was used in answering the research questions while Chi-square was used to test the hypotheses. All hypotheses were tested at .05 probability level of significance.

Presentation of Results: The results are hereby presented in the following ways:

(a) Answering of the Research Questions: Research question 1: To what extent will age influence road-safety practices among taxi
drivers in Uyo metropolis of Akwa Ibom State? 
Table 1: Frequency/Percentage Analysis of Road-Safety Practices among Taxi Drivers in Uyo Metropolis Based on Age (n=147).

\begin{tabular}{|c|c|c|c|c|c|c|c|c|c|c|c|c|c|c|c|c|c|}
\hline \multirow{3}{*}{$\begin{array}{l}\text { Age/Road-safety } \\
\text { strategies }\end{array}$} & \multicolumn{4}{|c|}{ Below 25 years } & \multicolumn{4}{|c|}{ 26-40years } & \multicolumn{4}{|c|}{ 41-55years } & \multicolumn{4}{|c|}{ 56years \& above } & \multirow[t]{3}{*}{ Total } \\
\hline & Ye & & & & Yes & & & Jo & & es & & No & $\mathbf{Y}$ & & & No & \\
\hline & f & $\%$ & f & $\%$ & f & $\%$ & & $\%$ & f & $\%$ & f & $\%$ & f & $\%$ & $\mathbf{f}$ & $\%$ & \\
\hline $\begin{array}{l}\text { 1.Mandatory training } \\
\text { /Licensing }\end{array}$ & 3 & 2.0 & 1 & 0.7 & 5 & 3.4 & 1 & 0.7 & 5 & 3.4 & 1 & 0.7 & 5 & 3.4 & 0 & 0 & \\
\hline $\begin{array}{l}\text { 2. Adequate vehicle } \\
\text { maintenance }\end{array}$ & 2 & 1.4 & 2 & 1.4 & 4 & 2.7 & 2 & 1.4 & 4 & 2.7 & 2 & 1.4 & 5 & 3.4 & 0 & - & \\
\hline $\begin{array}{l}\text { 3. Avoidance of risky } \\
\text { behaviours }\end{array}$ & 3 & 2.0 & 1 & 0.7 & 4 & 2.7 & 2 & 1.4 & 5 & 3.4 & 1 & 0.7 & 4 & 2.7 & 1 & 0.7 & \\
\hline $\begin{array}{l}\text { 4. Avoidance of intake } \\
\text { of alcohol/ drugs }\end{array}$ & 2 & 1.4 & 2 & 1.4 & 3 & 2.0 & 3 & 2.0 & 4 & 2.7 & 2 & 1.4 & 5 & 3.4 & 0 & - & \\
\hline $\begin{array}{l}\text { 5. Regular medical } \\
\text { check-up }\end{array}$ & 2 & 1.4 & 2 & 1.4 & 4 & 2.7 & 2 & 1.4 & 5 & 3.4 & 1 & 0.7 & 4 & 2.7 & 1 & 0.7 & \\
\hline 6. Good eating habit & 3 & 2.0 & 1 & 0.7 & 3 & 2.0 & 3 & 2.0 & 3 & 2.0 & 3 & 2.0 & 5 & 3.4 & 0 & - & \\
\hline $\begin{array}{l}\text { 7. Stress reduction/ } \\
\text { rest }\end{array}$ & 2 & 1.4 & 2 & 1.4 & 5 & 3.4 & 1 & 0.7 & 4 & 2.7 & 2 & 1.4 & 5 & 3.4 & 0 & - & \\
\hline Total & 17 & (11.6) & & (7.5) & 28 & (19.0) & 14 & (9.5) & 30 & (20.4) & 12 & $(8.2)$ & 33 & (22.4) & 2 & (1.4) & $147(100)$ \\
\hline
\end{tabular}

Table 1: Shows the frequency/percentage analysis of scores of road-safety practices among taxi drivers in Uyo metropolis based on age. The taxi drivers of age 56years and above had the highest scores of road-safety practices $33(22.4 \%)$, followed by those of age 41-55years with road-safety scores of $30(20.4 \%)$. The younger drivers of below 25years of age had the lowest scores of road-safety practices, $17(11.6 \%)$.

Research question 2: To what extent will educational qualification influence road-safety practices among taxi drivers in Uyo metropolis of Akwa Ibom State?

Table 2: Frequency/Percentage Analysis of Road-Safety Practices among Taxi Drivers in Uyo Metropolis Based on Education Qualification, (n=147).

\begin{tabular}{|c|c|c|c|c|c|c|c|c|c|c|c|c|c|c|c|c|c|}
\hline \multirow{3}{*}{$\begin{array}{l}\text { Education/ } \\
\text { Road-safety } \\
\text { strategies }\end{array}$} & \multicolumn{4}{|c|}{ Non formal education } & \multicolumn{4}{|c|}{ Primary education } & \multicolumn{4}{|c|}{ Secondary education } & \multicolumn{4}{|c|}{ Higher education } & \multirow[t]{3}{*}{ Total } \\
\hline & \multicolumn{2}{|c|}{ Yes } & \multicolumn{2}{|c|}{ No } & \multicolumn{2}{|c|}{ Yes } & \multicolumn{2}{|c|}{ No } & \multicolumn{3}{|c|}{ Yes } & \multirow{2}{*}{$\begin{array}{l}\text { No } \\
\%\end{array}$} & \multicolumn{4}{|c|}{ Yes $\quad$ No } & \\
\hline & f & $\%$ & f & $\%$ & f & $\%$ & & f $\%$ & $\mathbf{f}$ & $\%$ & f & & & $\%$ & f & $\%$ & \\
\hline $\begin{array}{l}\text { 1. Mandatory training/ } \\
\text { licensing }\end{array}$ & 3 & 2.0 & 2 & 1.4 & 4 & 2.7 & 1 & 0.7 & 5 & 3.4 & 2 & 1.4 & 5 & 3.4 & 0 & - & \\
\hline $\begin{array}{l}\text { 2. Adequate vehicle } \\
\text { maintenance }\end{array}$ & 3 & 2.0 & 2 & 1.4 & 4 & 2.7 & 2 & 1.4 & 4 & 2.7 & 2 & 1.4 & 4 & 2.7 & 0 & - & \\
\hline $\begin{array}{l}\text { 3. Avoidance of risky } \\
\text { behaviours }\end{array}$ & 2 & 1.4 & 2 & 1.4 & 3 & 2.0 & 2 & 1.4 & 4 & 2.7 & 3 & 2.0 & 5 & 3.4 & 0 & - & \\
\hline $\begin{array}{l}\text { 4. Avoidance of intake } \\
\text { of alcohol/ drugs }\end{array}$ & & 1.4 & 2 & 1.4 & 2 & 1.4 & 3 & 2.0 & 6 & 4.1 & 3 & 2.0 & 4 & 2.7 & 0 & - & \\
\hline $\begin{array}{l}\text { 5. Regular medical } \\
\text { check-up }\end{array}$ & 2 & 1.4 & 2 & 1.4 & 3 & 3.0 & 2 & 1.4 & 7 & 4.8 & 2 & 1.4 & 3 & 2.0 & 0 & - & \\
\hline 6. Good eating habit & 2 & 1.4 & 1 & 0.7 & 2 & 1.4 & 3 & 2.0 & 3 & 2.0 & 2 & 1.4 & 3 & 2.0 & 0 & - & \\
\hline $\begin{array}{l}\text { 7. Stress reduction/ } \\
\text { rest }\end{array}$ & 2 & 1.4 & 1 & 0.7 & 2 & 1.4 & 2 & 1.4 & 3 & 2.0 & 3 & 2.0 & 4 & 2.7 & 1 & 0.7 & \\
\hline Total & 16 & (10.9) & 12 & (8.2) & 20 & (13.6) & 15 & (10.3) & 32 & (21.8) & 17 & (11.6) & 34 & (23.1) & 1 & (0.7) & $147 / 100$ \\
\hline
\end{tabular}


Table 2: Shows the frequency/percentage analysis of road-safety practices among the taxi drivers in Uyo metropolis of Akwa Ibom State based on their educational qualification. The result showed that taxi drivers with tertiary education qualification had the highest score of road-safety practices of $34(23.1 \%)$ followed by drivers with secondary school qualification score of $32(21.8 \%)$. The least of the scores of road-safety practices among the taxi drivers in Uyo metropolis based on educational qualification was obtained by the drivers with no formal education $16(10.9 \%)$.

Research question 3: To what extent will marital status influence road-safety practices among taxi drivers in Uyo metropolis of Akwa Ibom State?

Table 3: Frequency/Percentage Analysis of Road-Safety Practices among Taxi Drivers in Uyo Metropolis based on Marital Status, $(n=147)$.

\begin{tabular}{|c|c|c|c|c|c|c|c|c|c|c|c|c|c|c|}
\hline \multirow[t]{2}{*}{$\begin{array}{l}\text { Marital status/ } \\
\text { Road-safety strategies }\end{array}$} & \multicolumn{4}{|c|}{$\begin{array}{ll}\text { Single } & \\
\text { Yes No }\end{array}$} & \multicolumn{2}{|c|}{$\begin{array}{l}\text { Married } \\
\text { Yes }\end{array}$} & \multicolumn{2}{|r|}{ No } & \multicolumn{5}{|c|}{ Divorced/widowed } & \multirow[t]{2}{*}{ Total } \\
\hline & $\mathbf{f}$ & & $\mathbf{f}$ & $\%$ & $\mathbf{f}$ & $\%$ & $\mathbf{f}$ & $\%$ & $\mathbf{f}$ & $\%$ & & f & $\%$ & \\
\hline $\begin{array}{l}\text { 1. Mandatory training/ } \\
\text { licensing }\end{array}$ & 5 & 3.4 & 2 & 1.4 & 6 & 4.1 & 3 & 2.0 & 6 & 4.0 & & 0 & - & \\
\hline $\begin{array}{l}\text { 2. Adequate vehicle } \\
\text { maintenance }\end{array}$ & 5 & 3.4 & 3 & 2.0 & 8 & 5.4 & 1 & 0.7 & 6 & 4.0 & & 1 & 0.7 & \\
\hline $\begin{array}{l}\text { 3. Avoidance of risky } \\
\text { behaviours }\end{array}$ & 4 & 2.7 & 2 & 1.4 & 6 & 4.1 & 4 & 2.7 & 7 & 4.7 & & 1 & 0.7 & \\
\hline $\begin{array}{l}\text { 4. Avoidance of intake of } \\
\text { alcohol/ drugs }\end{array}$ & 5 & 3.4 & 2 & 1.4 & 5 & 3.7 & 2 & 1.4 & 5 & 3.4 & & 0 & - & \\
\hline $\begin{array}{l}\text { 5. Regular medical } \\
\text { check-up }\end{array}$ & 3 & 2.0 & 4 & 2.7 & 5 & 3.4 & 2 & 1.4 & 5 & 3.4 & & 0 & - & \\
\hline 6. Good eating habit & 4 & 2.7 & 3 & 2.0 & 5 & 3.4 & 2 & 1.4 & 6 & 4.0 & & 0 & - & \\
\hline $\begin{array}{l}\text { 7. Stress reduction/ } \\
\text { rest }\end{array}$ & 4 & 2.7 & 3 & 2.0 & 5 & 3.4 & 2 & 1.4 & 4 & 2.7 & 1 & 1 & 0.7 & \\
\hline Total & 30 & (20.4) 1 & $9(12$ & & 40 & 27.2) & 16 & (10.9) & 39 & 6.5) & 3 & $(2$ & .1) & $147(100)$ \\
\hline
\end{tabular}

Table 3: Shows the frequency/percentage analysis of road-safety practices among taxi drivers in Uyo metropolis, based on their marital status. The taxi drivers that are married had the highest scores of good roadsafety practices, $40(27.2 \%)$, followed by the taxi drivers that are divorced/widowed with a score of $39(26.5 \%)$ while the lowest scores of road-safety practices was recorded among the taxi drivers who were single 30 $(20.4 \%)$.

\section{Research Question 4: To what extent will family size influence road-safety practices among taxi drivers in}

Uyo metropolis of Akwa Ibom State? 
Table 4: Frequency/Percentage Analysis of Road-Safety Practices among Taxi Drivers in Uyo Metropolis based on Family Size, $(n=147)$.

\begin{tabular}{|c|c|c|c|c|c|c|c|c|c|c|c|c|c|c|c|c|c|}
\hline \multirow{2}{*}{$\begin{array}{l}\text { Family size/Road- } \\
\text { safety strategies }\end{array}$} & \multicolumn{4}{|c|}{ 2-3 members } & \multicolumn{4}{|c|}{ 4-5 members } & \multicolumn{4}{|c|}{ 6-7 members } & \multicolumn{4}{|c|}{8 members and above } & \multirow[t]{2}{*}{ Total } \\
\hline & $\begin{array}{l}\mathbf{Y} \\
\mathbf{f}\end{array}$ & es & f & $\begin{array}{l}\text { No } \\
\quad \%\end{array}$ & $\begin{array}{l}\mathbf{Y} \\
\mathbf{f}\end{array}$ & es $\%$ & $\mathbf{f}^{1}$ & & Y & & $\mathbf{N}$ & & & es & f & $\%$ & \\
\hline $\begin{array}{l}\text { 1. Mandatory training/ } \\
\text { licensing }\end{array}$ & 9 & 6.1 & 1 & 0.7 & 5 & 3.4 & 1 & 0.7 & 3 & 2.0 & 1 & 0.7 & 2 & 1.4 & 2 & 1.4 & \\
\hline $\begin{array}{l}\text { 2. Adequate vehicle } \\
\text { maintenance }\end{array}$ & 8 & 5.4 & 1 & 0.7 & 5 & 3.4 & 1 & 0.7 & 2 & 1.4 & 2 & 1.4 & 2 & 1.4 & 2 & 1.4 & \\
\hline $\begin{array}{l}\text { 3. Avoidance of risky } \\
\text { Behaviours }\end{array}$ & 6 & 4.1 & 1 & 0.7 & 4 & 2.7 & 1 & 0.7 & 3 & 2.0 & 1 & 0.7 & 3 & 2.0 & 1 & 0.7 & \\
\hline $\begin{array}{l}\text { 4. Avoidance of intake } \\
\text { of alcohol/ drugs }\end{array}$ & 6 & 4.1 & 0 & - & 3 & 2.0 & 1 & 0.7 & 3 & 2.0 & 1 & 0.7 & 2 & 1.4 & 2 & 1.4 & \\
\hline $\begin{array}{l}\text { 5. Regular medical } \\
\text { check-up }\end{array}$ & 6 & 4.1 & 2 & 1.4 & 3 & 2.0 & 1 & 0.7 & 1 & 0.7 & 3 & 2.0 & 2 & 1.4 & 2 & 1.4 & \\
\hline 6. Good eating habit & 7 & 4.8 & 0 & - & 5 & 3.4 & 0 & - & 3 & 2.0 & 1 & 0.7 & 3 & 2.0 & 1 & 0.7 & \\
\hline 7. Stress reduction/ & 8 & 5.4 & 1 & 0.7 & 5 & 3.4 & 0 & - & 3 & 2.0 & 1 & 0.7 & 3 & 2.0 & 1 & 0.7 & \\
\hline
\end{tabular}

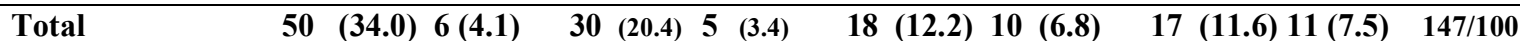

Table 4: Shows the frequency/percentage analysis of road-safety practices of taxi drivers in Uyo metropolis, based on their family sizes. The taxi drivers with 2-3 family members had the highest scores of good road-safety practices, $50(34.0 \%)$ followed by those with $4-5$ family members, $30(20.4 \%)$; while the drivers with highest numbers of family members ( 8 and above) exhibited the lowest level of road-safety practices, $17(11.6 \%)$.

Research Question 5: To what extent will income level influence road-safety practices among taxi drivers in Uyo metropolis of Akwa Ibom State?

Table 5: Frequency/Percentage Analysis of Road-Safety Practices among Taxi Drivers in Uyo Metropolis Based on Income Level (Per Week).

\begin{tabular}{|c|c|c|c|c|c|c|c|c|c|c|c|c|c|c|c|c|c|}
\hline \multirow{2}{*}{$\begin{array}{l}\text { Income level/ } \\
\text { Road-safety } \\
\text { strategies }\end{array}$} & \multicolumn{4}{|c|}{ Below $¥ 20,000$} & \multicolumn{4}{|c|}{$21,00030,000$} & \multicolumn{4}{|c|}{$31,000-40,000$} & \multicolumn{4}{|c|}{ 41, 000 and above } & \multirow[t]{2}{*}{ Total } \\
\hline & $\begin{array}{l}\mathbf{Y} \\
\mathbf{f}\end{array}$ & $\begin{array}{l}\text { es } \\
\%\end{array}$ & $\mathbf{f}^{1}$ & & & $\begin{array}{l}\text { es } \\
\%\end{array}$ & f & $\begin{array}{r}\text { No } \\
\%\end{array}$ & $\begin{array}{l}\text { Yes } \\
\text { f }\end{array}$ & $\%$ & $\begin{array}{l}\mathbf{N} \\
\mathbf{f}\end{array}$ & $\%$ & $\begin{array}{c}\text { Yes } \\
\mathbf{f}\end{array}$ & & f & $\%$ & \\
\hline $\begin{array}{l}\text { 1. Mandatory training/ } \\
\text { licensing }\end{array}$ & 4 & 2.7 & 0 & - & 4 & 2.7 & 1 & 0.7 & 5 & 3.4 & 2 & 1.4 & 6 & 4.1 & 1 & 0.7 & \\
\hline $\begin{array}{l}\text { 2. Adequate vehicle } \\
\text { maintenance }\end{array}$ & 3 & 2.0 & 1 & 0.7 & 3 & 2.0 & 2 & 1.4 & 6 & 4.1 & 1 & 0.7 & 5 & 3.4 & 0 & - & \\
\hline $\begin{array}{l}\text { 3. Avoidance of risky } \\
\text { Behaviours }\end{array}$ & 3 & 2.0 & 1 & 0.7 & 3 & 2.0 & 2 & 1.4 & 4 & 2.7 & 1 & 0.7 & 6 & 4.1 & 0 & - & \\
\hline $\begin{array}{l}\text { 4. Avoidance of intake } \\
\text { of alcohol/ drugs }\end{array}$ & 4 & 2.7 & 0 & - & 4 & 2.7 & 1 & 0.7 & 5 & 3.4 & 2 & 1.4 & 5 & 3.4 & 0 & - & \\
\hline $\begin{array}{l}\text { 5. Regular medical } \\
\text { check-up }\end{array}$ & 2 & 1.7 & 2 & 1.4 & 2 & 1.4 & 3 & 2.0 & 4 & 2.7 & 2 & 2.0 & 3 & 2.0 & 0 & - & \\
\hline 6. Good eating habit & 3 & 2.0 & 1 & 0.7 & 4 & 2.7 & 1 & 0.7 & 5 & 3.4 & 0 & - & 9 & 6.1 & 0 & - & \\
\hline $\begin{array}{l}\text { 7. Stress reduction/ } \\
\text { rest }\end{array}$ & 3 & 2.0 & 1 & 0.7 & 3 & 2.0 & 2 & 1.4 & 4 & 2.7 & 1 & 0.7 & 6 & 4.1 & 1 & 0.7 & \\
\hline Total & 22 & 15.0) & , & & $3(1$ & 5.6) 1 & & & $33(22$ & & & & 40 & $(27.2)$ & 2 & (1.4) & $147 /(100)$ \\
\hline
\end{tabular}


Table 5: Shows the frequency/percentage analysis of road-safety practices among taxi drivers in Uyo metropolis, Akwa Ibom State based on their income level. The taxi drivers with highest income level per week $\$ 41,000$ and above per week had the highest scores of good road-safety practices, $40(27.2 \%)$ followed by those with $\$ 31,000$ - $\$ 40,000$ per week, 33 (22.4\%); while those drivers of below $\$ 20,000$ per week had the lowest road-safety practices score of $22(15.0 \%)$.

Research Question 6: To what extent will beliefs about causes of RTA influence road-safety practices among taxi drivers in Uyo metropolis of Akwa Ibom State?

Table 6: Frequency/Percentage Analysis of Road-Safety Practices among Taxi Drivers in Uyo Metropolis Based on their Beliefs about Causes of RTA.

\begin{tabular}{|c|c|c|c|c|c|c|c|c|c|c|c|c|c|c|c|c|c|}
\hline $\begin{array}{l}\text { Beliefs/Road-safety } \\
\text { strategies }\end{array}$ & & $\begin{array}{l}\text { lll-luck } \\
\text { Yes } \\
\%\end{array}$ & $\mathbf{f}$ & $\begin{array}{l}\text { e } \\
\text { No } \\
\text { \% }\end{array}$ & \multicolumn{4}{|c|}{$\begin{array}{l}\text { Bad roads/ } \\
\text { environmental factors } \\
\text { Yes } \quad \text { No } \\
\text { f } \% \text { f } \%\end{array}$} & $\begin{array}{l}\text { W } \\
\text { po } \\
\text { f }\end{array}$ & $\begin{array}{l}\text { itchcraf } \\
\text { wers } \\
\text { es }\end{array}$ & $\begin{array}{l}\text { /den } \\
\text { f }\end{array}$ & $\begin{array}{l}\text { ionic } \\
\% \\
\%\end{array}$ & \multicolumn{4}{|c|}{$\begin{array}{l}\text { Carelessness of } \\
\text { the drivers/others }\end{array}$} & Total \\
\hline $\begin{array}{l}\text { 1. Mandatory training/ } \\
\text { licensing }\end{array}$ & 3 & 2.0 & 2 & 1.4 & 4 & 2.7 & 2 & 1.4 & 3 & 2.0 & 2 & 1.4 & 4 & 2.7 & 1 & 0.7 & \\
\hline $\begin{array}{l}\text { 2. Adequate vehicle } \\
\text { maintenance }\end{array}$ & 2 & 1.4 & 2 & 1.4 & 5 & 3.4 & 1 & 0.7 & 5 & 2.7 & 1 & 0.7 & 5 & 3.4 & 0 & - & \\
\hline $\begin{array}{l}\text { 3. Avoidance of risky } \\
\text { behaviours }\end{array}$ & 3 & 2.0 & 2 & 1.4 & 4 & 2.7 & 2 & 1.4 & 4 & 2.0 & 2 & 1.4 & 4 & 2.7 & 0 & - & \\
\hline $\begin{array}{l}\text { 4. Avoidance of intake } \\
\text { of alcohol/ drugs }\end{array}$ & 3 & 2.0 & & 0.7 & 5 & 3.4 & 1 & 0.7 & 4 & 2.0 & 2 & 1.4 & 5 & 3.4 & 0 & - & \\
\hline $\begin{array}{l}\text { 5. Regular medical } \\
\text { check-up }\end{array}$ & 2 & 1.4 & & 1.4 & 4 & 2.7 & 2 & 1.4 & 3 & 1.4 & 3 & 2.0 & 5 & 3.4 & 0 & - & \\
\hline 6. Good eating habit & 2 & 1.4 & 1 & 0.7 & 4 & 2.7 & 2 & 1.4 & 5 & 2.0 & 2 & 1.4 & 5 & 3.4 & 0 & - & \\
\hline $\begin{array}{l}\text { 7. Stress reduction/ } \\
\text { rest }\end{array}$ & 2 & 14 & 1 & 0.7 & 4 & 2.7 & 2 & 1.4 & 4 & 2.7 & 2 & 0.7 & 5 & 3.4 & 1 & 0.7 & \\
\hline Total & 17 & (11.0) & 11 & (7.4) & 30 & (20.4) & 12 & (8.8) & 28 & (19.0) & 14 & (9.5) & 33 & $(22.4)$ & 2 & (1.4) & 147(100) \\
\hline
\end{tabular}

Table 7: Shows the frequency/percentage analysis of road-safety practices among the taxi drivers in Uyo metropolis of Akwa Ibom State based on their beliefs about causes of RTA. The taxi drivers that believed that accident is caused by carelessness of drivers/other road users had the highest score of road-safety practices 33 $(12.9 \%)$; followed by those that believed that road traffic accident is caused by bad roads/environmental factors $30(20.4 \%)$. The lowest scores of road-safety practices were recorded by those that believed that accident is caused by ill-lucks/fate, 17 (11.6\%).

\section{(b) Testing of Hypothesis}

Research Hypothesis 1: Age will not significantly influence road-safety practices among taxi drivers in Uyo metropolis of Akwa Ibom State. 
Table 7: Chi-square Analysis of Road-Safety Practices of Taxi Drivers in Uyo

Metropolis based on Age $(n=147) \quad X^{2}=\underline{\Sigma(O-E)^{2}}$

$\mathrm{E}$

\begin{tabular}{l|ccc}
\hline $\begin{array}{l}\text { Scores of Road-Safety Practices } \\
\text { of Taxi Drivers based on Age }\end{array}$ & Yes & No & Total \\
\hline Below 25years & 17 & 11 & 28 \\
$26-40$ years & 28 & 14 & 42 \\
$41-55$ years & 30 & 12 & 42 \\
$56 y e a r s$ and above & 33 & 2 & 35 \\
\hline Total & $\mathbf{1 0 8}$ & $\mathbf{3 9}$ & $\mathbf{1 4 7}$
\end{tabular}

Computed $\mathrm{X}^{2}=11 ; 31$, degree of freedom $(\mathrm{df})=3$, while critical table value $=7.82$ at .05 level of significance

Table 7 shows the Chi-square analysis of score of road-safety practices of taxi drivers in Uyo metropolis based on age. Since the computed $X^{2}(11.31)$ is greater than the critical table value (7.82) at df of 3 and .05 level of significance, the null hypothesis $\left(\mathrm{H}_{0}\right)$ is thereby rejected. Therefore, age had significantly influenced road-safety practices among taxi drivers in Uyo metropolis, Akwa Ibom State.

Research Hypothesis 2: Educational qualification will not significantly influence road-safety practices among taxi drivers in Uyo metropolis of Akwa Ibom State.

Table 8: Chi-square Analysis of Road-Safety Practices of Taxi Drivers in Uyo metropolis based on their educational qualification $\mathrm{X}^{2}=\frac{\sum(\mathrm{O}-\mathrm{E})^{2}}{\mathrm{E}}$

\begin{tabular}{l|ccc}
\hline $\begin{array}{l}\text { Scores of Road-Safety Practices } \\
\text { based on Educational Qualification }\end{array}$ & Yes & No & Total \\
\hline Non formal Education & 16 & 12 & 28 \\
Primary Education (FSLC) & 20 & 15 & 35 \\
Secondary Education (SSC) & 32 & 17 & 49 \\
Tertiary Education (OND) & 34 & 1 & 35 \\
\hline Total & $\mathbf{1 0 2}$ & $\mathbf{4 5}$ & $\mathbf{1 4 7}$ \\
& & &
\end{tabular}

Table 8 shows the Chi-square analysis of scores of road-safety practices among taxi drivers in Uyo metropolis based on educational qualification. Since the computed $\mathrm{X}^{2}(17.53)$ is greater than the critical table $\mathrm{X}^{2}(7.82)$ at $\mathrm{df}$ of 3 and .05 alpha level; the null hypothesis is rejected. This implied that there was a positive statistical influence of educational qualification on road-safety practices among taxi drivers in Uyo metropolis, Akwa Ibom State. 
Research Hypothesis 3: Marital status will not significantly influence road-safety practices among taxi drivers in Uyo metropolis of Akwa Ibom State.

Table 9: Chi-square Analysis of Road-Safety Practices based on Marital Status of Taxi Drivers in Uyo Metropolis $\mathrm{X}^{2}=\underline{\Sigma(\mathrm{O}-\mathrm{E})^{2}}$

$\mathrm{E}$

\begin{tabular}{l|ccc}
\hline $\begin{array}{l}\text { Scores of Road-Safety Practices } \\
\text { based on Marital Status }\end{array}$ & Yes & No & Total \\
\hline Single & 30 & 19 & 49 \\
Married & 40 & 16 & 56 \\
Divorced/Widowed & 39 & 3 & 42 \\
\hline Total & $\mathbf{1 0 9}$ & $\mathbf{3 8}$ & $\mathbf{1 4 7}$ \\
\hline
\end{tabular}

Computed $\mathrm{X}^{2}=12.15 ; \mathrm{df}=2$, table value $=5.99$ at .05 level of significance

Table 9 shows the Chi-square analysis of scores of road-safety practices among taxi drivers in Uyo metropolis based on marital status. Since the computed $X^{2}(12.15)$ is greater than the critical table $X^{2}$ value (5.99), the null hypothesis $\left(\mathrm{H}_{\mathrm{o}}\right)$ is rejected, meaning that there was a positive significant influence of marital status on roadsafety practices among taxi drivers in Uyo metropolis.

Research Hypothesis 4: Family size will not significantly influence road-safety practices among taxi drivers in Uyo metropolis of Akwa Ibom State.

Table 10: Chi-square Analysis of Road-Safety Practices of Taxi Drivers in Uyo Metropolis based on their Family Sizes $\quad X^{2}=\underline{\Sigma(O-E)^{2}}$

$\mathrm{E}$

\begin{tabular}{l|ccc}
\hline $\begin{array}{l}\text { Scores of Road Safety Practices } \\
\text { based on family size }\end{array}$ & Yes & No & Total \\
\hline $2-3$ members & 50 & 6 & 56 \\
$4-5$ members & 30 & 5 & 35 \\
$6-7$ members & 18 & 10 & 28 \\
8 members and above & 17 & 11 & 28 \\
\hline Total & $\mathbf{1 1 5}$ & $\mathbf{3 2}$ & $\mathbf{1 4 7}$ \\
\hline
\end{tabular}

The computed $\mathrm{X}^{2}=13.38 ; \mathrm{df}=3$ and the critical table value $=7.82$ at .05 level of significance

Table 10 shows the Chi-square analysis of scores of road-safety practices of taxi drivers in Uyo metropolis based on family size. Since the computed $\mathrm{X}^{2}(13.38)$ is greater than critical table value $\mathrm{X}^{2}(7.82)$, the null hypothesis is therefore rejected; meaning that family size was statistically significant on the road-safety practices among taxi drivers in Uyo metropolis of Akwa Ibom State. 
Research Hypothesis 5: Income level will not significantly influence road-safety practices among taxi drivers in Uyo metropolis of Akwa Ibom State.

Table 11: Chi-square Analysis of Road-Safety Practices among Taxi Drivers in Uyo metropolis based on their income level

$$
\mathrm{X}^{2}=\frac{\sum(\mathrm{O}-\mathrm{E})^{2}}{\mathrm{E}}
$$

\begin{tabular}{l|crc}
\hline $\begin{array}{l}\text { Scores of Road Safety Practices } \\
\text { based on income level per week }\end{array}$ & Yes & No & Total \\
\hline Below N 20, 000 & 22 & 6 & 28 \\
$21,000-30,000$ & 23 & 12 & 35 \\
$31,000-40,000$ & 33 & 9 & 42 \\
41,000 and above & 40 & 7 & 42 \\
\hline Total & $\mathbf{1 1 8}$ & $\mathbf{2 4}$ & $\mathbf{1 4 7}$ \\
\hline
\end{tabular}

Computed $\mathrm{X}^{2}=10.76 ; \mathrm{df}=3$; while critical table value $=7.82$ at .05 level of significance

Table 11 shows the Chi-square analysis of scores of road-safety practices of taxi drivers in Uyo metropolis based on income level. Since the computed $\mathrm{X}^{2}(10.76)$ is greater than that the critical table $\mathrm{X}^{2}$ value (7.82), the null hypothesis $\left(\mathrm{H}_{\mathrm{o}}\right)$ is therefore rejected. This implied there was a significant statistical influence of income level on road-safety practices among taxi drivers in Uyo metropolis, Akwa Ibom State.

Research Hypothesis 6: Beliefs about causes of RTA will not significantly influence road-safety practices among taxi drivers in Uyo metropolis of Akwa Ibom State.

Table 12: Chi-square Analysis of Road-Safety Practices of Taxi Drivers in Uyo Metropolis based on their beliefs about the causes of RTA.

$$
\mathrm{X}^{2}=\frac{\sum(\mathrm{O}-\mathrm{E})^{2}}{\mathrm{E}}
$$

\begin{tabular}{l|ccc}
\hline $\begin{array}{l}\text { Scores of Road Safety Practices } \\
\text { based on drivers beliefs about }\end{array}$ & Yes & No & Total \\
causes of RTA & & & 35 \\
\hline Ill-luck/fate & 17 & 11 & 28 \\
Bad road/environmental factor. & 30 & 12 & 42 \\
Witchcraft/other demonic powers. & 28 & 14 & 42 \\
Carelessness of drivers/other road & 33 & 2 & $\mathbf{1 4 7}$ \\
users & & & $\mathbf{3 9}$ \\
\hline Total & $\mathbf{1 0 8}$ & &
\end{tabular}

Computed $\mathrm{X}^{2}=16.82 ; \mathrm{df}=3$; critical table $\mathrm{X}^{2}$ value $=7.81$ at .05 level of significance 
Table 14: Shows the Chi-square analysis of score of road-safety practices among taxi drivers in Uyo metropolis of Akwa Ibom State, based on their beliefs about causes of RTA. Since the computed $\mathrm{X}^{2}(16.82)$ is greater than the critical table $\mathrm{X}^{2}(7.81)$ at .05 significance level, the null hypothesis is rejected, implying that there was a significant statistical influence of the drivers beliefs about causes of RTA on their road-safety practices in Uyo metropolis.

\section{Discussion of findings}

The result of analysis of hypothesis 1 revealed significant statistical influence of age on road-safety practices of taxi drivers in Uyo metropolis. The older and experienced drivers were found to be more careful in observing road safety rules and practices than the younger and new drivers. The finding was in consonance with other previous studies, such as Williams (1999); Akinlade and Brieger (2004); Lafont, Amoros, Gadegbeku and Lawman (2009) and Okafor, Odeyemi and Dolapo (2013) who had earlier reported better road-safety practices among different group of drivers in their studies. The authors noted that older drivers were more careful to adhere to road-safety practices for prevention of road traffic accident. Furthermore, the authors also observed that the younger and newer drivers were always showing greater magnitude of carelessness, impatience and often in much haste, without paying adequate attention to road signs, traffic orders and other aspects of roadsafety practices, and therefore were more frequent to involve in a greater number of road crashes.

This finding also agreed with Adisa (2010) and Agbonkhese et al (2013) who observed that the younger/newer drivers on the roads were suffering from inexperience and were often thrown into greater confusion with no sense of responsibility at the advent of any form of danger while driving. Therefore the finding in this study affirmed that most of the younger drivers lack the necessary driving skills, adding that majority of the younger motorists are culprits of drugs and alcohol use. However, Langford, Bohensky and Newslead (2008) obtained negative statistical influence of age and road-safety practices and contradicted the present finding, saying that the age of motorists do not affect their driving skill of the drivers, but rather their intake of alcohol/other intoxicants.

The analysis of hypothesis 2 showed positive statistical influence of educational qualification on roadsafety practices of taxi drivers in Uyo metropolis; which implied that better educational qualification influenced taxi drivers' road safety practices in Uyo Metropolis. The finding agreed with that of Mayhew and Simpson (2002) who reported positive relationship between education and better road-safety practices among motorists in their study. These authors explained that good level of education and training was capable and effective to contribute to the prevention of road traffic crashes. They concluded that drivers' education had much value in enhancing safety to themselves and their passengers, as well as other road users, because of their ability to read and interpret road signs readily on their own.

In contrast, Okafor et al (2013) posited that better educational level/qualification of drivers can only increase the knowledge of the drivers, but have no effect on their road-safety practices. The authors argued that the impact of education on drivers' adherence to road-safety practices is uncertain and explained that education alone cannot improve the driver's road-safety practices, when there is no corresponding improvement in their welfare packages especially, improvement in the driver's income level.

The analysis of hypothesis 3: revealed significant statistical influence of marital status on road-safety practices of taxi drivers in Uyo metropolis. The finding agreed with Broughton (2005) and Johnell, Laflamme, Moller and Monarrez-Espino (2014), who reported that married drivers had lower crash rate than unmarried or single drivers. The authors acknowledged that married men tend to be more careful with conscious commitment to their daily driving, while the single drivers are careless to observe safety precautionary measures, and are therefore exposed to greater number of traffic crashes. Similarly, Morowatis (2010) reported that risky driving and neglect of safety precautions are higher among single motorists than their married counterparts. The present researcher explained that most married men may consider their safety as paramount for the survival of their families and therefore would love to observe all safety rules to ensure crash free driving for the good of their entire family's members.

The result of analysis of hypothesis 4 showed significant statistical influence of income level on the road-safety practices of taxi drivers in Uyo metropolis, which imply that income level of the driver was found to influenced to their adherence to ideal road safety practices. The finding agreed with Asafe et al (2015), who reported that poor socio-economic level of drivers was one of the major contributing factors for the increased number of road crashes in Ethiopia. The authors explained that poverty was one of the major reasons why most of the commercial drivers usually drive at high speed, ignoring relevant road signs and traffic orders in order to 
make more turns per day. Such high-speed driving lead to several cases of road crashes with accompanied traffic injuries.

Similarly, Adisa (2010) and Burn (2012) also reported poor adherence to road-safety standards among lower income drivers, explaining that many of such drivers are unable to undertake adequate maintenance of their vehicles and such may contribute to increase the number of road crashes. However, Tinureh et al (2014) reported negative statistical association of income level with the drivers' road-safety practices and asserted that the drivers' poor attitudes toward traffic safety were associated with drivers' level of alcohol and drug use rather than their socio-economic status.

The analysis of hypothesis 5 showed an existence of positive statistical influence of family size on roadsafety practice of taxi drivers in Uyo metropolis. The finding agreed with the previous studies of Adisa (2010) and Tiruneh et al (2014) who reported positive association of family size with road-safety practice. These authors explained that drivers with many children or more number of persons to provide for in their families are not always able to observe and adhere to ideal road-safety practices. This is because greater numbers of children/persons in their families require greater income for food, clothing and education. Therefore, such drivers at many instances commit several traffic offenses, such as over-speeding to make more turn per day and non-adherence to basic traffic rules and regulations. However, Zadok, Krawchuk and voas (2000) and Morowatis (2010) who obtained negative statistical association of family size to the driver's road-safety practices contradicted the finding of the present study.

The analysis of hypothesis 6 showed significant statistical influence of beliefs about causes of RTA on road-safety practices of taxi drivers in Uyo metropolis. The findings agreed with Kayani (2011) who reported that driver's beliefs' on fatalism influenced their daily driving behaviour. The author explained that drivers that believe that RTA is caused by ill-luck/fate are always reluctant to observe the basic road-safety practices; because such belief barriers the drivers from recognising factors that are associated with road crash causation thereby exposing them to multiple road crashes. The finding also agreed with Kouabenan (1998) and Ogo (2007) who asserted that the drivers' fatalistic beliefs influenced their perception of road crashes and consequently made them to take risks and neglect ideal road-safety measures.

\section{Conclusions/Recommendation}

Based on the findings of the study, it was concluded that social variables (specifically, age, educational qualification, marital status, family size and income level have positive influence on road-safety practices of taxi drivers in Uyo metropolis of Akwa Ibom State. The taxi drivers' beliefs about causes of RTA were also found to have positive influence on their road-safety practices. Intensive health education/road safety campaign was recommended at motor parks and other public places to inculcate safety consciousness among drivers and other road users in Uyo Metropolis as well as other parts of the state and beyond.

\section{References}

Abraham, E., Ezeque, U., Umeh, R., \& Ekanem, U. (2010). Causes of visual impairment among commercial drivers in Uyo metropolis, Akwa Ibom State. Orient Journal of Medicine, 1 (4), 34-41.

Adisa, R. S. (2010). The use of intoxicants among rural commercial motorists in Kwara State. Nigeria Journal of Social Sciences, 2 (2), 85-91.

Agbonkhese, O., Yisa, E., Agbonkhese, G., Akambi, D., Aka, E., \& Mondigha, E. (2013). Road traffic accident in Nigeria: Causes and prevention measures. Civil and Environmental Research, 3 (13), 90-99.

Akambi, D., Aka, E., \& Mondigha, E. (2013). Road traffic injuries on Nigeria roads and measures of prevention. Environmental Research Journal, 3 (1), 8-19.

Akinlade, O. C., \& Brieger, W. R. (2004). Taxis and road safety services in South Western Nigeria. International Quarterly Journal of Community Health Education, 2 (1), 17-23.

Akwa Ibom State Government Diary (2014). Uyo metropolis \& other council Headquarter in Akwa Ibom State. Uyo: Akwa Ibom State Government Press.

Alex, G., \& Cavel B. G. (2008). The life model of social work practice: Advances in theory and surveys in social research. Social Work Research, 6 (23), 241-246.

Asafe, N. G., Ingale, L., Shumey, A, \& Yang, H. (2015). Prevalence and factors associated with road traffic crashes among drivers in Mckelle Town, Northern Ethiopia. Public Library of Science Journal, 10 (3), $152-159$. 
Asogwa, S. E. (2007). Road traffic accidents in Nigeria: A review and reappraisal publication. Medicine Journal 3 (15), 586-592.

Blanchard, H. T., \& Tabloshi, P. A. (2006). Motorist safety: Educating drivers/riders at the teachable moment. Journal of Emergency Nursing, 3 (4), 330-332.

Broughton, P. S. (2005), Designing training to match driver's goals in driving behaviour and training. Transport Research Journal, 2, 25-26.

Bun, E. (2012). Road traffic accident in Nigeria: A Public health problem. African medical journal, 3 (2), 46-54.

Diez Roux, A. I. (2005). Social variables and their measurement in epidemiologic studies. Retrieved from:http:// com.nationalacadimics.org.//media108E487C39F7647A78DB3DD50B04BCF62.ashx.

Gupta, P., \& Ghai, O. P. (2007). Textbook of Preventive and Social Medicine. New Delhi: Satieties Kumar Jain Publishers.

Johnell, K., Laflannme, L., Moller, J., \& Monarrez-Espino (2014). The influence of marital status on drivers' road-safety practices toward prevention of traffic injuries from road traffic crashes. PLOS Journal, 9 (1), 522-529.

Kayani, A. (2011). Fatalism, superstition, religion and culture that influence road user's beliefs and behaviours in Pakistan: A thesis submitted to the Centre for Accident Research \& Road Safety, Queensland University of Technology, Pakistan.

Kouabenan, D. (1998). Beliefs and the perception of risk and accident. Risk Analysis, 18 (3), 243-252.

Lafont, S., Amoros, E., Gadegbeku, B., \& Lawman, B. (2009). The impact of driver's age on lost life years for other road users on France: A population based study of crash involved road users. Occupational and Environmental Epidemiology, 1, 69-81.

Langford, J., Bohensky, M., \& Newstead (2008). Do older drivers pose greater risk to other road users? Traffic Injury Preview, 9, (3), 181-196.

Lawrenzo, W. L. (2006). Social research methods: Qualitative and quantitative approaches (6th ed). New York: Ally and Bacon publishers.

Lum, H., \& Reagan, J. (1996). Interactive highway design model: Accident predictive model. Public Road and Federal Highway Administration Periodical, 59 (2), 18-22.

Mayhew, D. R., \& Simpson, H. (2002). The safety value of driver's education and training. Injury Prevention Journal, 8, 113-118.

Morowatis, M. A. (2010). The health belief model variables as predictors of risky behaviour among commuters in Yazd, Iran. Traffic injury. 11 (1), 141-148.

Ndiyo, N. A (2005). Fundamentals of research in behavioural sciences and humanities. Calabar: Wusen Publishers.

Ogo, A. O. (2007). Causes of road accident: An accident free society. Road Science, 13, 29-38.

Okafor, I., Odeyemi; K., \& Dolapo, D.C. (2013). Knowledge of commercial bus drivers about road safety measures in Lagos, Nigeria. Annal of African Medicine, 12, 1234-1239.

Sumaila, A. F. (2013). Road crashes, trend and safety management in Nigeria. Journal of Geography and Regional Planning, 6 (3), 53-62.

The Nigerian Police Force (2015). Police records on vehicle accidents in Uyo, Akwa Ibom State. Uyo: The Nigerian Police Force State Headquarter Bulletin.

Tiruneh, B., Daclew, B., \& Bifftu, B. (2014). Incidence of road traffic injuries and associated factors among patients visiting Emergency Department of Tikur Ambessa Teaching Hospital, Addis Ababa. Emergency Medicine International, 2 (1), 61-66.

Trochim, M. K. (2006). Kariables: Research methods knowledge base. Retrieved from: $\underline{w w w . s o c i a l r e s e a r c h m e t h}$ ods.net.kb/variable.php.

Uyo Metropolis Drivers Union (2015). The total number of drivers of the 5 main routes operated by taxi drivers in Uyo metropolis. Uyo: Uyo Township Drivers' Union.

WHO (2004). Road safety and prevention of accident. A brochure for World Health Day (7th April, 2004). Geneva: WHO Publication.

WHO (2009). Global status report on road safety: Time for action. Geneva: World Health Organization Publication.

Williams, A. F. (1999). Graduated licensing to the United State drivers. Journal of Injury Prevention, 5, 133135.

Zador, P. L., Krawchuk, S. A., \& Voas, R. B. (2000). Alcohol related risk of driver fatalities and driver involvement in fatal crashes in relation to driver age and gender. Journal of Alcohol, 61 (3), 387-95. 